Руденко О.М., доктор наук з державного управління, професор, директор науково-дослідного інституту публічного адміністрування та менеджменту Чернігівського національного технологічного університету (м. Чернігів, Україна)

\title{
ІНТЕГРАЦІЯ ЯК ФЕНОМЕН СУСПІЛЬНИХ ТРАНСФОРМАЦІЙ
}

У статті розкриваються різні підходи до розуміння сутності поняття «інтеграчія» та відображаються основні тлумачення цього терміну в науковій літературі.

Ключові слова: інтеграційні прочеси, інтеграція, соціосистема, трансформачія.

The article reveals different approaches to understanding the essence of the concept of "integration" and reflects the main interpretations of this term in the scientific literature.

Key words: integration processes, integration, sociosystem, transformation.

Взаємодія між основними підсистемами суспільного життя формує головний принцип внутрішньодержавних стосунків, а відкритість суспільної системи щодо зовнішньої взаємодії є основою стосунків міжнародних. При цьому пріоритетом в обох випадках лишається політична сфера та політичне співробітництво, що визначає напрям руху держави, іії імідж на міжнародній арені та ефективність суспільного розвитку. Головне місце у міжнародному просторі нині відводиться інтеграційним процесам. Поняття інтеграції пов'язане із зміцненням взаємозалежності і злагодженості елементів соціальної системи.

У науковій літературі на сучасному етапі відсутня єдність у розумінні інтеграції як поняття. Зазвичай інтеграцію відносять до сфери створення новітніх структур, що спрямовані на забезпечення регулювання взаємовідносин між державами на основі інституціоналізації самих міждержавних відносин (інтегрально-державницький підхід). Дещо окремо знаходиться розуміння інтеграції як природного процесу розвитку співробітництва між країнами однієї географічної зони (економікогеографічний підхід) поряд 3 майже повним ототожненням інтеграції 3 процесом створення наднаціональних органів, що супроводжується зменшенням ролі національних органів у прийнятті рішень (інституціональноуправлінський підхід). Також досить часто поняття інтеграції розглядають в аспекті розвитку світового господарства, визначаючи інтеграцію як процес створення бажаної структури світового господарства шляхом усунення штучних перепон ефективного функціонування суб'єктів господарської 
діяльності на основі уніфікації та координації всіх елементів цієї структури (функціонально-макроекономічний підхід Я.Тінбергена). Подібні розбіжності в розумінні інтеграції потребують урахування змісту та сутності інтеграційних процесів, їх особливостей у більш широкому контексті.

У сучасних дослідженнях термін інтеграція означає певну цілісність, структурованість суспільних відносин, об'єднання людей та держав у нові суспільно-політичні спільноти. Н. Овчаренко [1] наводить дві основні характеристики інтеграції: як соціальний процес утворення цілісності (єдності) системи з частин, систем, елементів (при цьому цілісність системи $\epsilon$ більшою, ніж сума іiі частин); як лояльність стосовно нових учасників процесу, визначення необхідних меж влади. Фактично він стверджує, що інтеграція може одночасно розглядатися як стан і як процес. При цьому тенденції інтеграції як стану відображають об'єктивний стан світової спільноти на тому чи іншому етапі, невизначений характер іiі розвитку; тенденції інтеграції як процесу є найбільш високим рівнем взаємодії, коли його учасники відчужують частину свого суверенітету на користь наднаціональних органів [2]. Таке розуміння $є$ ідеальним типом інтеграції, при якому відбувається не просто координація суспільно-політичних міждержавних відносин, а передача управління, автономії та суверенітету новоствореним державним структурам, які формують єдину політичну та економічну спільноти.

Основу інтеграції становить міжсистемна взаємодія суспільнополітичної, соціально-економічної, науково-технологічної, соціокультурної сфер суспільного життя, які, з одного боку, прагнуть до національного самозбереження, а 3 іншого, відчуваючи зовнішню залежність, мають схильність до саморуйнування. При цьому міжсистемна взаємодія розглядається у двох площинах: внутрішня та зовнішня. Внутрішня міжсистемна взаємодія визначає спроможність держави до нових міждержавних утворень і формується на основі взаємодії основних рівнів суспільного розвитку - свідомісного, політичного, економічного, соціального i культурного. Сдність та стабільність такої взаємодії забезпечує державі спроможність до самоорганізації, адаптації до умов зовнішнього середовища, активне включення у процеси міжнародних зв'язків, зберігаючи при цьому національну самобутність. В іншому разі інтеграційні процеси призведуть до поглинання держави та відкинуть iї на периферію глобалізаційного простору.

Зовнішня взаємодія визначає спроможність держави підтримувати свій імідж на міжнародній арені. Ефективність зовнішньої міжсистемної взаємодії залежить головним чином від внутрішньої стабільності держави та ефективної системи управління інтеграційними процесами. Така взаємодія є найбільш високою формою співпраці на міжнародній арені з метою створення єдиного геополітичного простору, але вона має певні обмеження, на практиці безпосередньо пов'язані 3 нестабільністю основних сфер життєдіяльності суспільства, що найбільш гостро виражається на рівні економічному, 
політичному, соціальному, етнокультурному, геополітичному відтворюючись у процесі дестабілізації суспільства та маючи наслідком дезінтеграцію системи.

Відповідно до розуміння сутності інтеграційних процесів, їх природи, спрямованості, специфіки виділяють такі ознаки інтеграції: взаємопроникнення i переплетіння національних виробничих процесів; широкий розвиток міжнародної спеціалізації і кооперації у виробництві, науці, техніці на основі найбільш прогресивних їх форм; глибокі структурні зрушення в економічних системах країн-учасниць; необхідність цілеспрямованого регулювання інтеграційного процесу, розроблення скоординованої економічної стратегії та політики; регіональність територіальних масштабів. Наведені ознаки характеризують процес інтеграції в різних аспектах - від економічних до політико-правових, дещо окремо знаходяться питання військової інтеграції. При цьому кожен тип інтеграції має власні специфічні функціональні характеристики, які безпосередньо впливають на теоретико-методологічні підходи іï дослідження.

В основі розбіжностей у розумінні інтеграції - не тільки нетотожність дослідницького підходу та сфери розгляду явища інтеграції як такого, але й, перш за все, теоретичні розбіжності, неоднорідність концепцій інтеграції, що інколи доходить до взаємовиключення. Складність ситуації зумовлена кількома причинами, серед яких чи не найгостріше стоїть питання філософського підгрунтя, на якому будуються концепції інтеграції. Адже саме вирішення цього питання безпосередньо впливає на зміщення концептуально важливих пріоритетів у той чи інший бік, побудову відповідних глобалістських геополітичних теорій та концепцій, й, як наслідок, концепцій інтеграції, в рамках яких здійснюються спроби на основі конкретного дослідницького підходу вирішувати питання світового розвитку різних (у тому числі й за розумінням) цивілізацій, культур, суспільств, держав.

Наприклад, у рамках історичного підходу розвивалися концепції еволюції та етногенезу. В концепції еволюції А.Тойнбі на основі аналізу розвитку цивілізацій стверджував, що на один історичний об'єкт (цивілізація, держава тощо) впливає певний комплекс чинників (як соціальних, так і природних). Проте об'єктивні умови зовнішнього середовища, наприклад, географічні, самі по собі не є чинниками, що за рахунок свого впливу $є$ причиною утворення соціальної спільноти, оскільки лише створюють умови, в яких спільноти стоять перед необхідністю здійснити вибір: або зникнути, або ж у процесі активної життєдіяльності розвивати власну соціальну організацію. Власне, за А.Тойнбі, розвиток соціальної організації спільноти $є$ фактично наслідком вимушеної реакції на зовнішні обставини, що реалізується в різних формах від простіших форм прояву (виживання) до більш складних (творчість), тобто відбувається внаслідок реалізації “життєвого пориву”. Проте вплив 
зовнішнього середовища у цьому випадку, оскільки невизначеним залишається питання безпосередньої участі особистості у процесі розвитку соціальної організації спільноти, дещо нагадує теорію суспільного договору Гоббса, в якій людина була змушена створити суспільство у відповідь на диктат зовнішніх обставин (необхідність збереження власного життя в складних умовах природного існування, страх перед силою тощо). Причому, якщо у Гоббса подальший розвиток соціальної спільноти також відбувається за договором, то А.Тойнбі фактично стверджує, що особливості цивілізаційного розвитку соціальної спільноти залежать передусім від природних умов зародження та існування тієї або іншої цивілізації та необхідності забезпечення ii безпеки.

На противагу такому підходу існують концепції наукового осмислення складних соціальних явищ і процесів (управління суспільним розвитком), що підкреслюють Ф.Лейн, В.Остром, Р.Стілльман, Дж.Фредеріксон. Одним 3 провідних елементів таких концепцій стає здатність управлінської системи регулювати зміни, що відбуваються в суспільстві, тобто забезпечувати умови не тільки для гнучкого реагування на них, але й створювати підгрунтя для їх наукового передбачення та вироблення дієвих механізмів управління суспільними змінами, подолання їх наслідків.

Теоретичним підгрунтям аналізу розвитку соціальної спільноти та суспільних процесів виступає не стільки соціально-філософський, або ж управлінський контекст, скільки традиційний для західної суспільної думки соціологічний підхід. Так, П. Штомпка [3] досліджує соціологію соціальних змін, вказуючи на відображення динаміки сучасності в активізації теорії змін. Він зазначає, що на теоретичному рівні динаміка наукового осмислення соціальних процесів відбувалася на кількох етапах: еволюційному, циклічному, діалектичному та посторієнтованому на розвиток. У межах цих етапів П.Штомпка намагається переосмислити концепції соціального процесу, розвитку, прогресу, соціального часу, історичної традиції, сучасності, постмодернізму, інтеграції та глобалізації.

У свою чергу, концепція етногенезу Л.Гумільова практично заперечує ідею впливу на розвиток цивілізацій історичних умов, пропонуючи замість концепції “життєвого пориву”, що розуміється як географічний процес, концепцію пасіонарності, в якій “життєвий порив” є лише продуктом історичних та природних умов. При цьому не підвладний впливу соціальноекономічних чинників певний фактор етногенезу стає за Л.Гумільовим основою розвитку цивілізації. Відповідно етнос у Л.Гумільова являє собою природно-географічну спільноту людей, об'єднаних за певним стереотипом поведінки на основі протиставлення себе іншим спільнотам, засадах позитивної компліментарності, i характеризується як енергетична система 3 мозаїчною структурою. Замість “творчості” А.Тойнбі, Л.Гумільов уводить поняття “зусилля", що передбачає використання в процесі перетворення умов соціального існування історично обумовленої енергійності людини, що 
виходить за межі виживання індивіда. При цьому особистість у рамках концепції пасіонарності фактично знеособлюється - в історичному процесі діють пасіонарії, гармонійні особи, субпасіонарії, що $є$ носіями різної енергетичної напруги, недетермінований вихід якої у зовнішнє середовище (об’єктивація “життєвого пориву” у А.Тойнбі) призводить до тих чи інших цивілізаційних зсувів. Але відсутність будь-якої причинності та детермінації в процесі реалізації енергетичної напруги створює необхідність містичного пояснення самої пасіонарності та відповідного пасіонарного розвитку цивілізації.

У контексті інтеграційних процесів в останні роки саме поняття “енергії" набуло дещо іншого змісту, особливо в рамках теорії самоорганізації системи, в синергетичних інноваційних концепціях. У роботах $[4 ; 5 ; 6]$ питання самоорганізації розглянуто в контексті синергетичних уявлень про соціальну реальність шляхом здійснення теоретичних досліджень соціальності, визначення проблемного поля самоорганізації системи, моделювання розвитку системи на основі самоорганізації.

В основі процесу самоорганізації, як зазначає А.Колєсніков, лежить принцип підпорядкування, відповідно до якого система може бути представлена як певна складність ієрархічного порядку елементів, що складається з сукупності динамічних підсистем, які підпорядковані одна одній і знаходяться між собою в чітко визначеному динамічному зв'язку [7]. При цьому доцільно розрізняти самоорганізацію (відкритість) соціальної системи (соціосистеми): самоорганізацію біомаси соціуму та соціальноцивілізаційну самоорганізацію. Ці рівні узалежнюють один одного, проте структурно як вхідні та вихідні потоки, так і механізми самоорганізації цих рівнів різні: продуценти самоорганізації біомаси можна вважати вхідними потоками у систему другого рівня - соціально-цивілізаційну [8].

Основними характеристиками процесу самоорганізації соціальної системи можна вважати: збільшення власної незалежності від зовнішнього середовища впорядкованості, що визначається закономірностями функціонування самої системи (ця впорядкованість формує первинну структуру системи, яка забезпечує необхідний запас різноманіття для формування структур вищих рівнів); відображення в різноманітті елементів первісної структури і їх різноманіття, і структури зовнішнього середовища; життєздатність і гомеостатична стійкість системи, що визначається тим, наскільки повно і адекватно вона відображає зовнішнє середовище, i тим, наскільки повно реалізовано в системі прагнення до побудови власної незалежної впорядкованості [9]. В контексті інтеграційних процесів самоорганізація соціальної системи передбачає іiі внутрішню структурну перебудову, поглиблюючи наднаціональний елемент; та зовнішню трансформацію формуючи на якісно вищому рівні нову структуру, що сприяє зближенню рівнів розвитку країн у всіх галузях, зберігаючи при цьому 
функціональність та формуючи стійку рівновагу до аналогічних збурень, що забезпечує найвищий ступінь витривалості системи в момент флуктуацій.

Проте зазначені концепції поки що не отримують належного визнання, натомість головну роль відіграють концепції, пов'язані 3 процесами соціального, економічного та політичного розвитку суспільства загалом. Активізація досліджень соціального розвитку здійснюється в межах неоліберальної парадигми (В.Холден [10]), що підпадає критиці за соціальні наслідки управлінських дій, які виявляються у зростанні нерівності щодо розподілу суспільних благ та влади. Як підкреслює В.Холден, у країнах, що розвиваються, забезпечення стійкого соціального розвитку безпосередньо залежить від реалізації принципів постмодерністського державного управління, парадигма якого передбачає залучення зусиль бідних прошарків населення до процесів соціального розвитку суспільства поряд із збереженням сталого розподілу влади в суспільстві, що повинно реалізуватися в програмах щодо забезпечення стійкого розвитку та створенні перспективних планів на майбутні періоди.

Аналіз кризи неолібералізму, яка нівелює значення суспільних інститутів та організацій, у тому числі й міжнародних, здійснюють Н.Хорєва і С.Бабб [11]. У контексті глобалізму в його неоліберальному варіанті дослідники доходять висновку про небезумовність теорії гегемоністської стабільності, адже деякі міжнародні інститути стали продуктом реалізації гегемоністського проекту, що вплинуло на визначення їх інституційних особливостей, внаслідок чого виникає проблема глобального управління такими складним структурами.

Неолібералізм, залишаючись одним з провідних теоретичних принципів аналізу суспільних явищ і процесів у межах інституціоналізму, насправді має дуальний характер - 3 одного боку, розвиток інституціональної теорії дає можливість розширити межі економічної та політичної теорії в межах інтеграції, а 3 іншого - загострює проблему “практикоорієнтованості" суспільного розвитку, яка зводиться переважно до питань взаємодії органів державної влади з інститутами громадянського суспільства, залишаючи за межами теоретичного мислення проблематику регулювання процесів соціального розвитку суспільства.

Спорідненою неолібералізму виступає конвенціональна концепція, запропонована В.Козловським, відповідно до якої соціальний розвиток розуміється як будь-яка зміна (порушення) соціального договору або соціальної конвенції на користь будь-якої групи індивідів. Комплексна картина соціального розвитку включає аналіз змін соціальних інститутів, норм, цінностей, внутрішніх механізмів суспільних змін, що виступають як взаємовідносини конфлікту й консенсусу (контракту, своєрідного договору). Соціальний розвиток проявляється як зміна соціальних практик та символічна боротьба в сфері політики та культури. При цьому спільним 
показником соціального розвитку є динаміка життєвого стандарту, якості життя, ступінь реалізації особистісного потенціалу.

І.Ясавєєв, навпаки, піддає ідею соціального розвитку сумніву. На підгрунті теорії Р.Нісбета, відповідно до якої в основі соціологічної ідеї розвитку міститься запозичена в біології метафора “зростання”, що визначає зміст теорії розвитку в аспекті уявлень про спрямованість, стадійність, незворотність історичних змін, про їх цілі тощо, незважаючи на тип суспільства, І.Ясавєєв вважає, що альтернативою ідеї соціального розвитку можуть виступати теорії соціальної онтології.

У результаті аналізу процесів розвитку в соціальній сфері А.Шаров виділяє такі чинники соціальних змін, що мають невибіркову дію й впливають водночас на всі головні складові суспільного розвитку, як: соціально-структурні зміни (суттєві зміни в соціальній структурі не обумовлюють значні зміни в свідомості людей - саме висока соціокультурна сталість буде визначати подальший розвиток); комунікативні процеси (за наявності високої інформованості населення та зовнішньої насиченості інформаційного поля фактологічною інформацією відзначаються сильні деформації у відборі інформації для "масового використання", іiі висока ідеологізованість та заангажованість 3MI). Характеризуючи трансформаційні процеси сучасного суспільства, А.Шаров зазначає, що важливою особливістю, яка стримує модернізаційну динаміку, $є$ синхронність перетворень як у ціннісній сфері та базисних механізмах соціального регулювання, так і в інституціональному середовищі. Ця синхронність, на думку дослідника, має аналогію з тезою про цивілізаційний характер кризи сучасного суспільства.

Л.Волчкова розкриває взаємозв'язок між ефективним управлінням i соціальним розвитком, під яким дослідниця розуміє складний, суперечливий, поступальний перехід або перетворення соціуму за допомогою визначених механізмів у результаті взаємодії внутрішніх та зовнішніх факторів, що обумовлюють цей процес. Соціальний розвиток $\epsilon$, на думку Л.Волчкової, розгортанням внутрішніх властивостей людини в ¥іi взаємозв'язках із соціумом, реалізацією та нарощенням соціального потенціалу. Соціальний розвиток відбувається в процесі подолання відчуження праці, розвитку, перетворення відносин власності, управління та влади. Відповідно ефективне управління соціальним розвитком є цілераціональним процесом узгодження суперечливих інтересів соціальних суб'єктів, що забезпечує реалізацію суспільних потреб та інтересів.

На основі аналізу взаємозв'язку змін, що відбуваються в суспільній праці, та змін в управлінні соціально-економічними процесами В.Мініна виділяє три основні тенденції в розвитку відносин управління: соціалізація управління, формування цілісного системно-управлінського мислення, відмова від структурно-функціонального підходу при формуванні моделі управління [12]. 
Питання сучасної соціальної теорії та природи теорії в соціальному світі досліджує Й.Крейб [13], намагаючись теоретично осмислити соціальну структуру в рамках теорії дії. Узгодженість цих двох теоретичних концептів утворюється в межах структурного функціоналізму Т.Парсонса, неофункціоналізму та теорії конфліктів, доповнених теоріями раціонального вибору та символічного інтеракціонізму. Значна увага приділяється також питанням застосування структуралістського варіанту марксизму i постмодерністської теорії, які поєднуються 3 критичною теорією Ю.Хабермаса. Зважаючи на таку теоретико-методологічну насиченість, наслідками дослідницького підходу стає конкретизація предмету соціальної теорії, який доповнюється практичним змістом, що дозволяє орієнтуватися в змінах сучасного суспільства, враховуючи їх вплив на теоретичну думку.

Інші дослідники розглядають процеси соціальної еволюції з точки зору динаміки нерівноважних систем. Л.Паутова, досліджуючи елементи системи, вказує на те, що вони наділені інтегральними якостями, тобто прагнуть підтримати цілісність системи, і зміни в одному 3 елементів безумовно призводять до змін в інших [14]. Це дає можливість стверджувати, що стан неврівноваженості системи свідчить про іiі готовність до здійснення структурно-функціональних та інституціональних змін і відповідно до збільшення різноманіття. В цьому сенсі $є$ показовим закон необхідного зростаючого різноманіття, за яким складність системи визначає складність суб'єкта - чим більше ускладнюється система, тим складнішим стає і суб'єкт. Лише за таких умов розвиток системи може бути динамічним, а зміни дозволять використати стан стійкої неврівноваженості в напрямі стабілізації системи. В якості основних змін необхідно розглядати зміни та трансформації світогляду суб'єктів в усіх сферах суспільного розвитку на основі пріоритету цінностей цивілізації.

У цьому випадку в якості чинників соціальної динаміки виділяються інформаціональність соціальних спільнот, тип і витратність управління, що розуміється як продукт взаємодії власної еліти і соціуму. Останній являє собою соціальну спільність, що актуалізує свої потенціальні керівні можливості. Відповідно суспільство розуміється як структура соціумів, що не взаємодіють. Безпосередньо узагальнюючим поняттям інформаціональних, соціальних та культурно-ціннісних змін, які визначають перехід від одного сценарію суспільного розвитку до іншого, $€$ певні еволюційні зсуви [15, с. 31$]$.

Значно розширює межі такого підходу теорія Дж.Херрера [16], який досліджує зв'язок між технологіями та міжнародною політикою, доводячи, що міжнародна політика формується під впливом технологій, які мають вирішальне значення, враховуючи темпи технологічних змін у суспільстві. Дослідження Дж.Херрера грунтується на теорії міжнародних відносин, історичній соціології, пропонуючи складну теорію історичного взаємозв'язку технологій і міжнародної політики, отримуючи нові результати у сфері 
аналізу політичної економіки та безпеки, що мають значення для управління суспільним розвитком у період глобалізації, демонструючи можливості міждисциплінарного підходу. Актуальним у цьому контексті виявляється аналіз системних змін, в основі яких - суспільні зсуви, здійснений у межах новітніх парадигм (перш за все нематеріалістичного розуміння структури), що наближує теоретичне осмислення технологій в державній політиці, державному управлінні, міжнародній політиці до сфери соціального з метою виходу на нову практику управління трансформаціями складних соціальних систем.

Розгляд суспільних трансформацій, у тому числі в аспекті інтеграційних процесів, спонукає деяких дослідників розглядати будь-які зміни з точки зору стану стабільності та хаосу. Наприклад, В.Романов вважає [17], що у “соціальному хаосі”, що виник, проявляється розділення суспільства на соціум i власну еліту. Відтворення власною елітою моделей управління, що грунтуються на попередньому досвіді, виявляється витратним і не досягає ні соціального, ні економічного ефекту. Намагаючись подолати загострення суспільних настроїв щодо змін та реформування політичної системи, власна еліта трансформує моделі керівних впливів. Але соціальна самоорганізація в умовах відкритого суспільства призводить до утворення неурядових структур, що генерують нові моделі прийняття рішень, які базуються на системному підході, в якому джерелами соціальної динаміки виявляються дихотомія влади (проявляється в характері взаємовідносин соціуму та владної еліти щодо ресурсів на основі різних систем цінностей) та чинники якості соціальних спільнот.

Система цінностей, інформаціональність (виступає як чинник дихотомії влади та соціальної динаміки й актуалізує управлінський потенціал соціальної спільності) та управлінська інноваційність відображають основу соціальних спільнот. Безпосередньо інноваційні моделі управління виникають як продукт взаємодії владної еліти та соціуму у відкритому навколишньому середовищі та впливають на еволюцію систем [15, с. 31$]$.

Слід вказати, що системний синергетичний підхід базується на використанні природничо-наукової та фізико-математичної наукових парадигм. У разі дослідження інтеграційних процесів використання системного синергетичного підходу дає вченим можливість стверджувати, що соціальна динаміка описується почерговою зміною періодів соціальних інновацій та спадів [18]. 3 огляду на це необхідним виявляється розгляд соціальної динаміки залежно від сполучення чинників інформаціональності соціуму, владної еліти та витратності управління як параметра стану системи. При цьому витратність управління визначається обсягом суспільних ресурсів, які можуть бути мобілізовані суб'єктом управління та впливають на характер соціальної динаміки і сценарій суспільного розвитку. Поряд 3 цим суспільні ресурси являють собою сполучення людського капіталу, ресурсів навколишнього середовища як середовища відтворення високоякісного 
людського капіталу та фінансово-промислових ресурсів як результату виробничої діяльності, що залежить від якості соціуму.

Аналіз процесів суспільного розвитку в умовах інтеграції наводить дослідників на думку, що при еволюційних зсувах, що протікають за законами системної катастрофи, яка супроводжується структурною дезінтеграцією та наступною інтеграцією 3 подальшою перебудовою взаємовідносин, формується якісно інше суспільство, 3 іншим характером соціальних взаємовідносин та сценарієм суспільного розвитку [15, с. 31.]. Особливого значення при цьому набувають методологічні проблеми дослідження, які грунтовно розкриваються в наукових підходах Д.Хітчінса [19], який зазначає, що сьогодні не існує єдиної наукової теорії, яка б поєднувала сукупність різних уявлень науковців, а також узагальнювала їх методологічні напрацювання та розробки, що обумовлює збереження догматизму в науці. Альтернативним підходом Д.Хітчінс розуміє системність та аналіз соціотехнічних систем, розвиток яких обумовлений виникненням концепції хаосу і катастроф, які встановлюють певні обмеження щодо застосування конкретної методології аналізу складних явищ i процесів, враховуючи динаміку змін у сучасних умовах суспільного буття як граничного стану для наукового пізнання. Д.Хітчінс пропонує уніфіковану систему гіпотез, що застосовує ентропійну конфігурацію, або уніфіковану концепцію, оскільки системи $\epsilon$ або реальними, такими, що можуть сприйматися, або ж усвідомлюються на основі редукції до хаосу, на основі чого вони осмислюються та визначаються. Уніфікована система гіпотез намагається зрозуміти системи шляхом дослідження складних систем усіх типів: фізичних, хімічних, біологічних, соціальних, екологічних тощо, не намагаючись піддавати критиці питання правильності або хибності управління ними.

Сім принципів побудови уніфікованої системи гіпотез, до яких належать реакція системи, системна сув'язність, адаптація системи, єдність у різноманітті, обмежене різноманіття, преференційні моделі та циклічна послідовність, пропонує Д.Хітчінс. Сукупність цих принципів становить певний план циклу життя не єдиної системи, а набору відкритих систем, що взаємодіють та можуть бути відображені. Ці принципи вказують на причини об'єднання систем у сукупність, появу хаотичних, катастрофічних, лінійних або пріоритетних взаємодій кожної 3 них, заснованої на їх стабільності, причинах занепаду або колапсу, a також перегрупування їх основних компонентів. Оскільки Д.Хітчінс пропонує представляти ці принципи в формі кінцевого / перехідного стану, то уніфікована система гіпотез $\epsilon$ фактично сумою принципів, а не одним конкретним принципом, адже описує етапи життєвого циклу системи та причини переходу 3 одного до іншого. Завдяки проходженню певних етапів, які поєднані в єдиний стабілізаційний (або синергетичний) цикл, здійснюються дослідження інтеграційних процесів на основі самоорганізації системи. "У більшості процесів синергетичний цикл замаскований формуванням потоку синергетичних подій, в якому 
початок одного циклу накладається на кінцевий або інший етап попереднього когерентного синергетичного циклу. Тільки імпульсні самоорганізаційні процеси є чіткими прикладами невеликої послідовності самоорганізаційних циклів". Відповідно до такого підходу I. Черленяк пропонує таку схему синергетичного циклу [8]: початковий стан базової системи; початковий стан плюс потоки енергії, речовини, інформації; дисипація (розсіювання) енергії та виникнення нерівноважного стану; фокусування та локалізація нерівноважності в центрах генерації; релаксація базової системи до початкового стану за одночасної генерації нової структури.

Проте наближення подібних теорій до теорії соціальних систем, маючи на меті вирішення проблем управління суспільним розвитком, не завжди виявляється вдалим, оскільки, як зазначає К.Фукс [20], теорія соціальних систем підпадає значному впливу з боку редукціоністського індивідуалізму та дуалістичного функціоналізму, в межах яких адекватне інтегрування людського неможливо. Щоб уникнути дуалізму, механістичного детермінізму та редукціонізму, К.Фукс пропонує діалектичну концепцію соціальних систем, що грунтуються на понятті самоорганізації. Діалектичну теорію соціальної самоорганізації К.Фукс намагається наповнити ідеями теорії структурації А.Гідденса, стверджуючи, що структури є середніми та результуючими дій (теорема дуальної структури), тобто водночас дозволяють і обмежують соціальні дії.

На основі цієї ідеї К.Фукс стверджує, що соціальні системи $є$ "рекреативними" (такими, що відтворюються), тобто такими, що самоорганізуються. Рекреативність у свою чергу грунтується на творчій активності людства, а соціальні структури стають дійсними завдяки продуктивній практиці та відносинам акторів людства. У цьому контексті проблема еволюційного розвитку розглядається К.Фуксом у неофункціоналістському аспекті: він визнає наявність важливих структурних елементів у соціальних системах, які сприяють історичному розвитку суспільства, що грунтується на діалектиці випадковості та необхідності, а також принципах порядку через флуктуації в умовах нестабільності та біфуркацій. Як підкреслює К.Фукс, всі системи, що самоорганізуються, є інформаційно-генеративними, впритул наближаючись до гідденсової концепції збереження механізмів, які допускають просторово-часове дистанціювання соціальних відносин, що дозволяє описувати відносини інформації та самоорганізації в соціальних системах.

Але подібний висновок $є$ певним поверненням до індетермінізму в розумінні процесів суспільного розвитку загалом. Зазначена проблема спонукає розглядати інтеграційні процеси 3 точки зору інноваційності, створення якісно нових соціальних спільнот, що потребує розвитку та впровадження новітніх механізмів управління подібними соціальними утвореннями, новітнім, інноваційним суспільством. 3 урахуванням цього доцільним є розроблення некласичних концепцій інтеграції, в яких би 
поєдналися принципи епістемології, еволюційної теорії, теорії дискурсу в межах єдиної парадигми. Такий підхід передбачає в якості підгрунтя політичний плюралізм та соціальну взаємодію, впливаючи на підвищення ефективності суспільного розвитку загалом.

Неоднозначність процесів світової глобалізації та інтеграції обумовлюють необхідність конкретизації зазначених наукових парадигм, що стають основою розуміння суспільного розвитку, теоретичною основою руху суспільства. Складність міжцивілізаційної комунікації призводить до необхідності врахування в теоретичних моделях суспільного розвитку багатьох його складових, що значно ускладнює як самі моделі, так і їхнє розуміння. Як наслідок, аналітично-прогностична діяльність починає спиратися на емпірично неверифіковані дані, методи аналізу $\epsilon$ недосконалими, що знижує їх результативність та ефективність. Але будь-яка модель є ідеальним відображенням об’єкта дослідження, його теоретичним конструктом, наданим у формальному вигляді, а іiі складність безпосередньо відображає складність об'єкта, що досліджується. I тому використання конкретної моделі в практичній діяльності потребує чіткого теоретикометодологічного підгрунтя - не однієї наукової теорії, парадигми, а всієї системи наукових знань та уявлень про об’єкт дослідження, що забезпечує цілісність та адекватність теорії та практики, спадковість наукових ідей i концепцій, що формує інноваційне поле суспільного розвитку.

Досліджуючи проблеми теоретико-методологічного

осмислення глобального людського розвитку, Р.Сміт зазначає, що багаторівневі статистичні моделі вивчення ефекту цивілізаційних зон та інструментальних факторів впливу на людський потенціал є важливими 3 точки зору виявлення потенціалу людського розвитку на рівні країни та суспільства [21]. Р.Сміт грунтується на показниках людського розвитку ООН - індексах, що синтезують рівень освіченості, тривалості життя та рівня доходів. До цієї групи він також додає показники рівня розвитку політичної демократії, корупції, внутрішніх конфліктів, оцінюючи їх як інструментальні фактори. При цьому важливим $\epsilon$ те, що політична свобода поєднується 3 громадянським обов'язком, що стає основою регіональних відмінностей в оцінці людського розвитку, а також розуміння того факту, що цивілізаційні зони та рівень корупції безпосередньо стають дестабілізуючими факторами, оскільки призводять до зсувів у структурі суспільств і деформації суспільнополітичного життя країни.

Можливість застосування у процесі моделювання складних соціальних систем методів математичного моделювання в межах математичної кінетичної теорії активних частин, що залишає можливість аналізу математичних моделей 3 соціальної точки зору, доводять Н.Белломо, М.Бертотті та М.Делітала [22]. Дослідники доходять висновку, що можливості такої моделі описувати процес впливу соціальної політики держави та розподілу суспільних благ на загальні тенденції розвитку 
суспільства є очевидними, навіть незважаючи на наявний в сучасній науці теоретико-методологічний плюралізм. В останньому випадку також доцільно звернути увагу на багаторівневу концепцію та методологію опису і аналізу стабільності систем, які пропонують Т.Баумгартнер, Т.Бьорнс та Д.Мікер [23].

Іншим провідним теоретичним принципом дослідження процесів інтеграції стає теорія гегемонії, особливо кількісна теорія гегемонії стабільності, яка $є$ основою наукового прогнозування змін внутрішньої i зовнішньої політики держави щодо економічного розвитку, приймаючи до уваги складову національної безпеки, що набуває актуальності за умов інтеграції та глобалізації. Враховуючи сучасні зміни в міжнародній економічній ситуації та необхідність коригування гегемонічної теорії стабільності, В.Коневей [24] вказує на актуальність іiі модифікації в аспекті модернізації методологічного підгрунтя дослідження економічних процесів на всіх рівнях управління державою та суспільством.

У рамках загальної суспільної проблематики М.Дейлі і Х.Сільвер [25] аналізують концепти соціального відчуження та соціального капіталу, вказуючи на виникнення внаслідок змішування або перекривання одного поняття іншим соціальної ізоляції. При цьому, як правило, соціальна ізоляція редукується до проблеми соціального капіталу, що звужує можливості розвитку державної політики, оскільки в основі певної теоретичної традиції фактично відсутнім $є$ осмислення процесів, в які включене конкретне соціальне явище. В цьому аспекті дослідники контекстуалізують соціальні відносини та соціальні мережі, піддаючи критиці політику “рішень”.

Дещо іншу точку зору обгрунтовує Дж.Чьопра [26], який вважає, що державне управління переважно займається управлінням змінами в гонитві за “суспільно визначеними” суспільними цінностями, намагаючись зберегти вигляд відкритості та прозорості. В теоретичному аналізі цього питання Дж.Чьопра звертається до аналізу процесу формування державної політики, суб'єктів державного управління та інститутів громадянського суспільства в аспекті поліпшення управлінської складової взаємозалежності цих двох систем, питань ролі та обов'язків політичного керівництва та керівників органів державної влади.

У цьому аспекті доцільно вказати на обмеженість застосування класичної парадигми державного управління до сучасних проблем, пов'язаних 3 динамічними змінами соціального середовища та необхідністю адекватних відповідей на зміни в соціальній системі, що потребує іншого теоретичного обгрунтування в теорії державного управління, ніж традиційний прагматизм. Так, досліджуючи проблему інституційних змін в рамках теорії організації, Ж.Берк i Д.Гелвен [27] доходять висновку про синтетичний характер організації, що обумовлює ii функціональну структуру, яка може бути рекомбінована, причому останнє залежить від культурних та інституційних ресурсів самої організації. Тобто фактично йдеться про теорію креативного 
синкретизму, яку дослідники розглядають як основу змін, що спирається на феноменологічний підхід в частині пояснення виникнення та закріплення інституційних норм і цінностей у суспільстві.

Застосування концепції досвіду як основи розуміння соціальних явищ в межах інституціоналізму певною мірою наближує ідеї Ж.Берка і Д.Гелвена до прагматизму Дж.Дьюї, особливо в аспекті розуміння соціальних норм. Саме у такому контексті Ф.Доббін [28] піддає критиці організаційну теорію, вказуючи, що байдужість аналізу в ї рамках залишає переконливим класичний підхід П.Бурдьє. Але на практиці виявляється, що цей підхід та організаційна теорія фактично застосовуються фрагментарно, на відміну від сучасних “парадигматичних" проектів як ключових у сучасному управлінні.

Найбільшого поширення в сенсі теоретико-методологічного обгрунтування інтеграційних процесів отримує економічна складова суспільного розвитку. При цьому в межах інноваційних концепцій пояснення економічної інтеграції передбачає врахування циклічного характеру розвитку світової економіки та використання принипів економічної синергетики. Як зазначає Н.Кондратьєв, певною мірою наслідуючи К.Маркса, соціальна динаміка описується почерговою зміною періодів соціальних інновацій та спадів [29]. Необхідним є введення в циклічну модель економіки, яка визначає інноваційний розвиток системи, принципу “межового циклу”. Розмежування сфер зворотного часу та незворотного еволюційного часу i нелінійних взаємодій призводить до виокремлення централізації та інтегрованості 3 економічного простору як суттєвих складових суспільної підсистеми, що розширює сферу дієвого впливу управління на незалежну в межах класичної економічної парадигми сферу ринкових відносин з метою забезпечення їх стабільності та запобігання утворенню криз.

У теоретико-методологічному плані введення в модель меж дозволяє поділити економічний простір з урахуванням не лише внутрішньосистемних переходів, але й конкретизації в межах інтеграційної парадигми, яка дозволяє наблизитися до практики за допомогою уявлення про системні переходи як такі, що знімають зовнішні границі та обмеження для економіки, що грунтується на інформації як аксіологічному пріоритеті суспільного розвитку. Встановлена межа між базовою структурою економічної системи та стратегічною структурою, що характеризує еволюційну тенденцію економічного розвитку, дозволяє відтворити загальну картину балансу розподілу основних ресурсів, що регулюють та спрямовують розвиток системи, тобто необхідно говорити про модель відтворення в межах інтеграційної парадигми. Принциповим моментом у цьому разі стає наявність специфічної централізації, що стає основою перетворення управлінської вертикалі в систему кластерів, яка $\epsilon$ шляхом запобігання дивергенції, а 3 іншого боку забезпечує конвергенцію державного регулювання економіки та базових регуляторів економічної підсистеми. 
В умовах інтеграції та глобалізації національних економічних систем у межах єдиного світового економічного простору це набуває особливого значення. Хоча 3 точки зору державного управління у цьому разі виникає доволі складна проблема, пов'язана 3 необхідністю контролю та регулювання системи економічних відносин у суспільстві, яке орієнтується на ліберальну модель економіки. Зрозумілість та дієвість механізмів державного регулювання економічних відносин у традиційних суспільствах (у тому сенсі, що вони не орієнтуються на виробництво інтелектуального продукту у формі знань та інформації) може втратити власну ефективність за умов поширення лібералізації національної економіки. Можливим рішенням може бути застосування різноманітних протекціоністських засобів, що, як зазначають дослідники [30], пом'якшують вплив глобалізації на існуючі вітчизняні сектори, включаючи приватний сектор, фірми державної форми власності, союзи й інші складові суспільства. Як альтернативний шлях вони можуть спробувати відкрити свої економіки для якомога більшої участі в міжнародній системі.

Врахування таких підходів при формуванні поліциклічної моделі інноваційного розвитку суспільства дозволить більш адекватно відображати динаміку та тенденції суспільних змін, оскільки статично-констатуючий характер, який дає можливість побудови прогнозних сценаріїв лише в умовах стохастичних еволюційних змін, набуде трансформаційного характеру в напрямі побудови динамічних моделей нестійкого розвитку. Сучасні умови суспільного розвитку, його динаміка, що прискорюється процесами глобалізації та інтеграції, впливаючи на те, що процеси суспільних змін набувають революційного характеру, не $є$ стійкими i, як наслідок, не $\epsilon$ рівноважними. Врахування цього дає можливість розширення методів наукового пошуку, розроблення інноваційних теоретичних конструктів i відповідного оновлення практики, оскільки, як зазначають дослідники, "розгляд еволюційної динаміки соціальних систем в моделях нестійких нерівноважних процесів формує нове знання" [18]. Така динаміка у розвитку соціальних систем характеризуються наявністю жорсткої ієрархічної взаємообумовленості між основними сферами та напрямами їх функціонування як всередині, так і з зовнішнім середовищем. Специфіка міжсистемної та внутрісистемної взаємодії як проблема стабілізації процесів суспільного розвитку, що розглядається в межах теоретичних парадигм, як правило, зіштовхується 3 відсутністю адекватної методологічної бази наукового аналізу складних систем без застосування методів математичного моделювання, що здійснюються на основі формалізації дослідницьких процедур. Зважаючи на їх ідеально-абстрактний характер, дослідницькі процедури не завжди прийнятні, оскільки зазвичай орієнтуються на верифікацію або вже отримані дані звітного періоду або ж на імовірнісні показники, що не можуть бути верифіковані в більш-менш близькому майбутньому. 
Оскільки рух та розвиток нерівноважних відкритих систем підпадає під вплив різних закономірностей, їх необхідно розглядати, перш за все, аналізуючи стан рівноваги / нерівноваги 3 позицій синергетики, коли під рівновагою розуміється такий стан системи, при якому іï макроскопічні параметри залишаються незмінними, тобто зберігаються стала структура, порядок функціонування, параметри входів і виходів, а на макрорівні відбувається адаптація зовнішніх викликів до структурно-функціональних характеристик системи. При цьому варто зазначити, що складні системи характеризуються певними особливостями функціонування у взаємодії 3 середовищем, що відображається на їх розвитку. Так, економічна система набуває динаміки в процесі зміни стану рівноваги, коли суспільна система втрачає стійкість, тобто змінюються параметри стаціонарної рівноваги, викликані впливом зовнішніх та внутрішніх збурень. Часові параметри змін у системі під впливом нестійкої рівноваги призводять до подальшого розвитку самої системи, яка набуває значної динаміки та якісних змін свого стану. У свою чергу, відкритість економічної системи зумовлює стримування ентропії, що може виникнути під впливом зовнішнього середовища. У цьому разі державне регулювання економіки, що підпадає під вплив зовнішнього середовища, може призводити до викривлень напряму та зменшення динаміки розвитку системи.

Аналіз змін, що відбуваються в економічній системі, пов'язаних 3 інтеграційними процесами, обумовлені в тому числі й зміною економічних циклів, динамікою науково- технічного розвитку. Це призводить до появи інновацій, потребує врахування наявності в нерівноважних системах петлі позитивного зворотного зв'язку, яка забезпечує в системі стан посилення слабких збурень, провокуючи виникнення структурних змін та обумовлюючи різкі якісні зміни, що не є еволюційними. Це дає можливість враховувати виникнення кумулятивного ефекту в процесі інтеграційного розвитку системи, оскільки передбачає застосування наукового прогнозування всієї сукупності причинно-наслідкових зв'язків в усі періоди.

При цьому, відповідно до принципу дисипації, різкі якісні зміни в розвитку суспільної системи можливі за умов досягнення іï параметрами певних критичних або біфуркаційних значень. У випадку економічної системи можна стверджувати наявність значної кількості біфуркаційних параметрів, оскільки існує значна кількість станів всіх елементів системи, пов'язаних з рівновагою.

Так, за умов економічної інтеграції має відбуватися адаптація стану системи до стану середовища водночас 3 набуттям системою якісних характеристик параметрів середовища, що призводить до змін критичних значень системи. Фактично зміна стану економічної системи в процесі інтеграції до світової економіки передбачає зміну параметрів соціальної системи відповідно до параметрів середовища в області джокерів за умов досягнення системою біфуркаційних значень. Стійкість, що виникає у такому 
випадку, $є$ запорукою підвищення рівноваги та стабільності розвитку економічної системи, що отримує значний поштовх до організаційних засад управління ними, гнучкості та здатності до відтворення під впливом змін середовища на основі диверсифікації поряд зі збереженням наявних позитивних структурно-функціональних елементів, що мають цінність для суспільного розвитку.

За умов несприйняття економічною системою викликів зовнішнього середовища, що потребують адаптивного врахування, система набуває стану розструктурування, тобто виникають умови для руйнування важливих структурних елементів та зв'язків у системі, що відповідно провокує стан так званої "негативної інтеграції. Відтак соціальна система стає більш нестійкою, що прискорює іiі входження в стан хаосу та виникнення протиріч перехідних станів. У цьому разі зовнішнє середовище утворює ентропійний ефект, зіштовхуючись з адаптивними можливостями соціальної системи та особливостями їі функціонування.

Отже, економічна складова інтеграційних процесів, вбудовуючись у соціальні моделі суспільного розвитку за принципами економічної синергетики, відображає бачення соціальних складностей. Оскільки соціальні складності обумовлені діалектичними протиріччями історичного роз- витку суспільства, то важливим є розгляд не тільки еволюційної динаміки змін в соціальних системах і самих соціальних систем, але й урахування темпів та напрямів змін у глобальному світі, їх інноваційного спрямування та ієрархічного характеру, що досить часто досягається завдяки революційним зрушенням.

Важливим при цьому видається використання принципу системного синтезу, який, як слушно зазначає М.Мойсеєв, дає можливість побудови ієрархії спрощених моделей, базові елементи яких можуть бути зрозумілі й легко пояснені, ієрархічно вищі елементи при цьому враховують різні фактори. При цьому дійсно важливим стає можливість виділення параметрів порядку, тобто незначної кількості перемінних, до яких підлаштовуються інші [31]. Сфера інноваційності, через яку проходить соціальна система, створює умови для формування якісно нового типу міжнародної взаємодії. 3 певною мірою припущення цей тип можна назвати інноваційною міжсистемною взаємодією, характерною особливістю якої стає иї актуальність в якості об'єкта, а також сфери вироблення державної політики на макро-та мікрорівні, що найбільш яскраво виявляється за умов економічної інтеграції.

При цьому макроекономічний рівень функціонування економічної системи $з$ точки зору економічної інтеграції, вбираючи в себе ефекти, що виникають на мікроекономічному рівні, формує простір та умови для перетворення загального зростання на ендогенність взаємодії основних соціально- економічних суб'єктів макросередовища системи в часовому вимірі, в межах якого відбувається загальне розгортання системи. Фактично 
йдеться про внутрішню еволюцію системи, що на рівні просторово-часового поля $є$ фазовою. Внутрішній потенціал для змін в економічній системі утворюється внаслідок взаємодії економічної макроструктури 3 основними елементами інших елементів суспільства на основі зростаючого ентропійного ефекту в межах синергетичного поля міжсистемної взаємодії, вивільняючи більше можливостей для реалізації потенціалу кожного окремого суб'єкта мікро-та макроекономічних відносин, підвищуючи ступінь свободи розвитку та самоорганізації системи.

За такого підходу побудова інноваційної моделі суспільного розвитку вимагає врахування ієрархічної структури соціуму, який певною мірою відрізняється від структури, що розглядається в класовому підході. Однак ієрархічність у цьому разі дає можливість лише абстрагуватися від соціальної дійсності та формалізувати певні теоретичні узагальнення у вигляді моделі. Проте аналіз тенденцій суспільного розвитку, його прогнозування потребує врахування особливостей антагоністичності соціальної структури суспільства в конкретно-історичних умовах, якщо навіть i не використовується безпосередньо класовий підхід.

Проте, як зазначає Ф.Фукуяма, владна еліта може взаємодіяти 3 інноваційним соціумом, протидіяти йому, або взагалі ігнорувати суспільні інновації. Вибір владної еліти також впливає на вибір суспільної системи в точці біфуркації. Ієрархічно правлячі еліти втрачають можливість утримувати зв'язки в інформаційному просторі, що стрімко розширюється [32]. У цьому сенсі важливим $\epsilon$ вирішення проблеми, що пов'язана з необхідністю створення нових структур у системі державного управління, орієнтованих на забезпечення ефективності європейської інтеграції.

\section{СПИСОК ВИКОРИСТАНИХ ДЖЕРЕЛ}

1. Овчаренко Н. Модели современных интеграционных процессов. [Електронний ресурс]. - Режим доступу: http://www.xserver. ru/user/msipr/

2. Попович А. Интеграция: теоретические аспекты. - [Електронний pecypc]. - Режим доступу: http://fmp-gugn.narod.ru/pop2.html

3. Sztompka P. The sociology of social change / Piotr Sztompka. - San Francisco, CA: Wiley-Blackwell, 1994. - 368 p.

4. Будущее России в зеркале синергетики / Под ред. Г. Малинецкого. M.: КомКнига: URSS, 2006. - 269 с. - (Серия "Синергетика: от прошлого к будущему. Будущая Россия").

5. Синергетическая парадигма. Социальная синергетика: [ред.- сост.: О. Астафьева, В. Буданов; редкол.: В. Василькова (отв. ред.) и др.]. - М.: Прогресс-Традиция, 2009. - 688 с.

6. Структуры и хаос в нелинейных средах / [Т.Ахромеева, С.Курдюмов, Г.Малинецкий, А.Самарский]. - М.: Физматлит, 2007. - 484, [4] c. 
7. Колесников А. Объективные законы единства процессов самоорганизации и управления / А. Колесников // Управление и информационные технологии (УИТ-2005): доклады 3-й Всероссийской научной конф., 30 июня - 2 июля 2005 г., Санкт- Петербург. Т. 1. - СПб: ЭТУ, 2005. - С. 5-21.

8. Черленяк I. Синергетика і проблеми оптимізації державного та соціального управління / I. Черленяк // Стратегічна панорама. - 2004. - №1 . C. 91-99.

9. Селезнев Г. Синергетическое мышление / Г. Селезнев // Экология. Экологическое образование. Нелинейное мышление: тезисы докладов III Междунар. конф. из серии “Нелинейный мир”, 22-27 сент. 1997 г., Воронеж. - Воронеж: [Б. м.], 1997. - С. 144-146.

10. Holden W. Post Modern Public Administration in the Land of Promise: The Basic Ecclesial Community Movement of Mindanao / William N. Holden // World Views: Global Religions, Culture, and Ecology. - 2009. - Vol. 13. - №2. P. 180-218.

11. Chorev N. The crisis of neoliberalism and the future of international institutions: A comparison of the IMF and the WTO / Nitsan Chorev, Sarah Babb // Theory and Society. - 2009. - Vol. 38. - №5. - P. 459- 484.

12. Вітер Д. Соціокультурна та ідеологічна трансформації суспільства в аспекті концепції гуманістичного розвитку / Д. Вітер // Вісник НАДУ. - 2006. - №2. - C. 369-376.

13. Craib I. Modern social theory : from Parsons to Habermas / Ian Craib. Basingstoke, UK: Palgrave Macmillan, 1992. - 276 p.

14. Гуц А. Глобальная этносоциология: учебн. пособ. / А.Гуц. - Омск : ОмГУ, 1997. - 212 с.

15. Костюк В. Теория эволюции и социоэкономические процессы / В. Костюк. - М.: УРСС, 2001. - 176 c.

16. Herrera G. Technology and International Transformation / Geoffrey L. Herrera. - New York, NY: State University of New York Press, 2006. - 275 p.

17. Романов В. Социально-инновационный вызов государственному управлению / В.Романов. - М.: Изд-во РАГС, 2006. - 92 с.

18. Курдюмов С. Синергетика - новые направления / С.Курдюмов, Г.Малинецкий, А.Потапов. - М.: Знание, 1989. - 64 с.

19. Hitchins D. A unified systems hypothesis / Derek K. Hitchins // Systemic Practice and Action Research. - 1993. - Vol. 6. - №6. - P. 613-645.

20. Fuchs Ch. Structuration theory and self-organization / Christian Fuchs // Systemic Practice and Action Research. - 2003 - V. 16 - №2. - P. 133-167.

21. Smith R. Global human development: accounting for its regional disparities / Robert B. Smith // Quality and Quantity. - 2009. - Vol. 43. - №1. - P. $1-34$. 
22. Bellomo N. From the kinetic theory of active particles to the modeling of social behaviors and politics / Nicola Bellomo, Maria Letizia Bertotti, Marcello Delitala // Quality and Quantity. - 2007. - Vol. 41. - № 4. - P. 545-555.

23. Baumgartner $\mathrm{T}$. The description and analysis of system stability and change : Multi-level concepts and methodology / Tom Baumgartner, Tom R. Burns, David L. Meeker // Quality and Quantity. - 1977. - Vol.11 . - №4. - P. 287328.

24. Conaway V. A Modified Theory of Hegemonic Stability / Vernon W. Conaway. - New York, NY.: DEC, 1994. - 192 p.

25. Daly M. Social exclusion and social capital : A comparison and critique / Mary Daly and Hilary Silver // Theory and Society. - 2008. - Vol. 37. - №6. - P. 537-566.

26. Chopra J. History And Theory Of Public Administration / J. Chopra. New Delhi: Commonwealth Publishers, 2004. - 342 p.

27. Berk G. How people experience and change institutions: a field guide to creative syncretism / Gerald Berk, Dennis Galvan // Theory and Society. - 2009. Vol. 38. - №6. - P. 543-580.

28. Dobbin F. The poverty of organizational theory: Comment on: "Bourdieu and organizational analysis" / Frank Dobbin // Theory and Society. 2008. - Vol. 37. - №1. - P. 53-63.

29. Кондратьев Н. Критические заметки о плане народного хозяйства / Н. Кондратьев // Большие циклы конъюнктуры и теория предвидения. - М.: Экономика, 2002. - С. 669-707.

30. Рут Ф. Міжнародна торгівля та інвестиції / Ф. Рут, А. Філіпенко; [пер. $з$ англ.: Д. Олесневич, О. Олесневич, П. Кузик]. - К.: Основи, 1998. $743 \mathrm{c}$.

31. Rudenko O. Economical stability of society: forecast models of unsustainable development / Rudenko Olga // Studia Universitatis "Vasile Goldiş". - 2010. - Anul 20. - Partea I. - p. 54-66. - (Seria: "ŞtiinŃe Economice).

32. Fukuyatma F. Death of hierarchy. From "The Great Description: Human Nature and the Reconstitution of Social Order" // Financial Times. - 1999. - June 12 / June 13.

\section{REFERENCES}

1. Ovcharenko, N. Modeli sovremennykh integratsionnykh protsessov [Models of modern integration processes].Retrieved from: http://www.xserver. ru/user/msipr/

2. Popovich, A. Integratsiya: teoreticheskiye aspekty [Integration: theoretical aspects]. Retrieved from: http://fmp-gugn.narod.ru/pop2.html

3. Sztompka, P. (1994). The sociology of social change. San Francisco, CA: Wiley-Blackwell.

4. Malinetskyy, G. (Eds.). (2006). Budushcheye Rossii v zerkale sinergetiki [The future of Russia in the mirror of synergetics]. Moscow: KomKniga: URSS. 
5. Astaf'yeva, O., Budanov, V., \& Vasil'kova, V. (Eds.). (2009) Sinergeticheskaya paradigma. Sotsial'naya sinergetika [Synergetic paradigm. Social synergetics]. Moscow: Progress-Traditsiya.

6. Akhromeyeva ,T., Kurdyumov, S., Malinetskiy, G., \& Samarskiy, A. (2007). Struktury i khaos v nelineynykh sredakh [Structures and chaos in nonlinear media]. Moscow: Fizmatlit.

7. Kolesnikov, A. (2005). Ob"yektivnyye zakony yedinstva protsessov samoorganizatsii i upravleniya [Objective laws of unity of processes of selforganization and management]. 5-21.

8. Cherlenyak, I. (2004).Synerhetyka i problemy optymizatsiyi derzhavnoho ta sotsial'noho upravlinnya [Synergetics and problems of optimization of state and social management]. Stratehichna panorama, 1, 91-99.

9. Seleznev, G. (1997). Sinergeticheskoye myshleniye [Synergetic thinking]. Proceedings from: IIII Mezhdunar. konf. iz serii "Nelineynyy mir" - The Third International. Conference from the series "Nonlinear World". (pp. 144146). Voronezh.

10. Holden, W. (2009). Post Modern Public Administration in the Land of Promise: The Basic Ecclesial Community Movement of Mindanao. World Views: Global Religions, Culture, and Ecology. (Vol. 13.), (pp. 180-218).

11. Chorev, N., \& Babb, S. (2009). The crisis of neoliberalism and the future of international institutions: A comparison of the IMF and the WTO. Theory and Society, 5, 459- 484.

12. Viter, D. (2006). Sotsiokul'turna ta ideolohichna transformatsiyi suspil'stva $\mathrm{v}$ aspekti kontseptsiyi humanistychnoho rozvytku [Socio-cultural and ideological transformation of society in the aspect of the concept of humanistic development]. Visnyk NADU, 2, 369-376.

13. Craib, I. (1992).Modern social theory : from Parsons to Habermas. Basingstoke, UK: Palgrave Macmillan.

14. Guts, A. (1997). Global'naya etnosotsiologiya [Global ethnosociology]. Omsk : OmGU.

15. Kostyuk, V. (2001). Teoriya evolyutsii i sotsioekonomicheskiye protsessy [The theory of evolution and socioeconomic processes] - M.: URSS,. - $176 \mathrm{~s}$.

16. Herrera, G. (2006). Technology and International Transformation. New York, NY: State University of New York Press.

17. Romanov, V. (2006). Sotsial'no-innovatsionnyy vyzov gosudarstvennomu upravleniyu [Socially-innovative challenge to the government]. Moscow: Izd-vo RAGS.

18. Kurdyumov, S., Malinetskiy, G., Kurdyumov, S., \& Potapov, A. (1989). Sinergetika - novyye napravleniya [Synergetics - new directions] Moscow: Znaniye.

19. Hitchins, D. (1993). A unified systems hypothesis. Systemic Practice and Action Research, 6, 613-645. 
20. Fuchs, Ch. (2003). Structuration theory and self-organization. Systemic Practice and Action Research, 2, 133-167.

21. Smith, R. (2009). Global human development: accounting for its regional disparities. Quality and Quantity, 1, 1-34.

22. Bellomo, N., Bertotti, M., \& Delitala, M. (2007). From the kinetic theory of active particles to the modeling of social behaviors and politics. Quality and Quantity, 4, 545-555.

23. Baumgartner, T., Burns, T., \& Meeker, D. (1977). The description and analysis of system stability and change : Multi-level concepts and methodology. Quality and Quantity, 4, 287-328.

24. Conaway, V. A (1994). Modified Theory of Hegemonic Stability New York, NY: DEC.

25. Daly, M., \& Silver, H. (2008).Social exclusion and social capital : A comparison and critique. Theory and Society, 6, 537-566.

26. Chopra, J. (2004). History And Theory Of Public Administration. New Delhi: Commonwealth Publishers.

27. Berk, G., \& Galvan, D. (2009). How people experience and change institutions: a field guide to creative syncretism. Theory and Society, 6, 543-580.

28. Dobbin, F. (2008). The poverty of organizational theory: Comment on: "Bourdieu and organizational analysis". Theory and Society, 1, 53-63.

29. Kondrat'yev, N. (2002). Kriticheskiye zametki o plane narodnogo khozyaystva [Critical notes on the national economy plan]. Moscow: Ekonomika.

30. Rut, F., \& Filipenko, A. (1998). Mizhnarodna torhivlya ta investytsiyi [International Trade and Investment]. (D. Olesnevych, O. Olesnevych, P. Kuzyk, Trans.). Kyiv: Osnovy.

31. Rudenko, O. (2010). Economical stability of society: forecast models of unsustainable development. Seria: "ŞtiinŃe Economice - Series: "Economic Sciences, I, 54-66.

32. Fukuyama, F. (1999). Death of hierarchy. From "The Great Description: Human Nature and the Reconstitution of Social Order". Financial Times. 